Departement für Kleintiere, Klinik für Kleintierchirurgie der Vetsuisse-Fakultät Universität Zürich

Vorsteher: Prof. Dr. med. vet. Antonio Pozzi DECVS, DACVS, DACVSMR

Arbeit unter wissenschaftlicher Betreuung von

Prof. Dr. med. vet. Antonio Pozzi DECVS, DACVS, DACVSMR

Predictors of comorbidities and mortality in cats with pelvic fractures

vorleget von

Zur Erlangung der Doktorwürde der

Vetsuisse-Fakultät Universität Zürich

\title{
Meike Hammer
}

Tierärztin

aus Dorsten, Deutschland

genehmigt auf Antrag von

Prof. Dr. med. vet. Antonio Pozzi DECVS, DACVS, DACVSMR, Referent 
Für meine Eltern. 


\section{Inhaltsverzeichnis}

1 Zusammenfassung in Englisch (Originalsprache) Seite 6

2 Zusammenfassung in Deutsch $\quad$ Seite 7

3 Manuskript: Veterinary Surgery, online publiziert 26.12.2019 Seiten 8-17

Abstract

Seite 8

Introduction

Seiten 8-9

Materials and methods

Seiten 9-10

Study design

Seite 9

Statistical analysis

Seite 10

Results

Seiten 10-15

Descriptive analysis

Seiten 10-11

Distribution of pelvic fractures

Seiten 11-12

Treatment of pelvic fractures

Seite 12

Additional injuries and acquired conditions

Seiten 12-14

Outcome

Seite 14

Risk factors for death

Seiten 14-15

Discussion

Seiten 15-16

Conflict of interest

Seite 16

References

Seite 17

4 Danksagung

5 Curriculum Vitae 


\title{
1 Zusammenfassung in Englisch
}

\begin{abstract}
Risk factors for comorbidities and death of cats with pelvic fractures where characterized and evaluated in this study.

Medical records were reviewed for cats in which pelvic fractures had been diagnosed (January 2003 to November 2016). Retrieved data included signalment, mechanism of injury, clinical findings, diagnostic imaging investigations, type and number of concurrent injuries based on anatomical location, type of therapy, and survival. Pelvic fractures were classified according to location and severity. Descriptive statistics were performed, and logistic regression models were constructed to examine associations between risk factors and outcome. Cases consisted of 280 cats with no (9\%), unilateral (43\%), and bilateral (48\%) involvement of the weight-bearing axis. Sacral fractures were found in $12 \%$ of cats. Surgical treatment and mortality rates increased progressively with the severity of the pelvic fractures $(\mathrm{P}<.001)$. Mean number of concurrent body regions injured was $2.4 \pm 1.2$ and was associated with mortality $(\mathrm{P}<.01)$. Twenty percent of cats did not survive to discharge. Cats with neurologic injuries were more likely not to survive $(\mathrm{P}=.02)$.

In conclusion, concurrent injuries to at least one body region, especially the abdomen and thorax, were observed in cats sustaining pelvic fractures. Mortality was associated with increased severity of the fractures, neurologic injuries, and increased number of concurrent injuries.
\end{abstract}

Keywords: cat, pelvis, pelvic fracture, polytrauma, mortality, injury 


\section{Zusammenfassung in Deutsch}

\section{Zusammenfassung}

In dieser Studie wurden Risikofaktoren für Komorbidität und Mortalität von Katzen mit Beckenfrakturen retrospektiv untersucht (2003 - 2016). Die erhobenen Daten umfassten Signalement, Verletzungsmechanismus, klinische Befunde, Art und Anzahl der Verletzungen, Behandlung und Überlebensrate. Beckenfrakturen wurden anhand ihrer Lage und Schweregrad klassifiziert. Beschreibende Statistiken und logistische Regressionsmodelle wurden angefertigt, um Zusammenhänge zwischen Risikofaktoren und Behandlungsergebnissen zu untersuchen. Zweihundertachtzig Katzen wurden untersucht, bei denen in $9 \%$ keine, in $43 \%$ unilaterale und in $48 \%$ bilaterale Frakturen der gewichtstragenden Beckenanteile festgestellt wurden. Sakrumfrakturen wurden bei $12 \%$ festgestellt. Abhängig vom Schweregrad der Beckenfrakturen stieg progressiv der Anteil chirurgisch behandelter Katzen als auch die Mortalitätsrate. Die Mortalitätsrate lag bei 20\%. Die durchschnittliche Anzahl zusätzlich verletzter Körperregionen betrug 2,4 $\pm 1,2$ und korrelierte mit der Mortalitätsrate $(\mathrm{P}<0,01)$. Katzen mit neurologischen Verletzungen hatten eine erhöhte Wahrscheinlichkeit zu versterben. Zusammenfassend kann gesagt werden, dass bei Katzen mit Beckenfrakturen zusätzliche Verletzungen in mindestens einer Körperregion, insbesondere dem Abdomen und Thorax, festgestellt wurden. Die Sterblichkeit korrelierte mit dem Schweregrad der Frakturen, neurologischen Verletzungen und der insgesamten Anzahl zusätzlicher Verletzungen. 


\title{
Predictors of comorbidities and mortality in cats with pelvic fractures
}

\author{
Meike Hammer, med vet ${ }^{1}$ ( ) | Andreas Gutbrod DECVS, Dr med vet ${ }^{2}$ | \\ Nadja E. Sigrist DECVECC, DACVECC, Dr med vet ${ }^{3} \quad \mid \quad$ Valentine Jacot, Dr med vet $^{4}$ | \\ Francesca Del Chicca DECVDI, Dr med vet ${ }^{5} \quad$ Richard Evans PhD ${ }^{6}$ | \\ Antonio Pozzi MS, DACVS, DECVS, DACVSMR, Dr med vet ${ }^{1}$
}

${ }^{1}$ Clinic for Small Animal Surgery, Vetsuisse Faculty, University of Zurich, Zurich, Switzerland

${ }^{2}$ Tierklinik Nürnberg Hafen, Nuremberg, Germany

${ }^{3}$ Division of Critical Care Medicine, Vetsuisse Faculty, University of Zurich, Zurich, Switzerland

${ }^{4}$ Neuchâtel, Switzerland

${ }^{5}$ Clinic for Diagnostic Imaging, Vetsuisse Faculty, University of Zurich, Zurich, Switzerland

${ }^{6}$ Chisago City, Minnesota

\section{Correspondence}

Antonio Pozzi, Clinic for Small Animal Surgery, Vetsuisse Faculty, University of Zurich, Winterthurerstrasse 260, CH-8057 Zurich, Switzerland.

Email: pozzi@vetclinics.uzh.ch

Present address

Meike Hammer, Clinique Vétérinaire

Aquivet, Eysines, France

\begin{abstract}
Objective: To characterize and evaluate risk factors for comorbidities and death of cats with pelvic fractures.

Study design: Retrospective case study.

Animals: Cats $(\mathrm{n}=280)$.

Methods: Medical records were reviewed for cats in which pelvic fractures had been diagnosed (January 2003 to November 2016). Retrieved data included signalment, mechanism of injury, clinical findings, diagnostic imaging investigations, type and number of concurrent injuries based on anatomical location, type of therapy, and survival. Pelvic fractures were classified according to location and severity. Descriptive statistics were performed, and logistic regression models were constructed to examine associations between risk factors and outcome.

Results: Cases consisted of 280 cats with no (9\%), unilateral (43\%), and bilateral (48\%) involvement of the weight-bearing axis. Sacral fractures were found in $12 \%$ of cats. Surgical treatment and mortality rates increased progressively with the severity of the pelvic fractures $(P<.001)$. Mean number of concurrent body regions injured was $2.4 \pm 1.2$ and was associated with mortality $(P<.01)$. Twenty percent of cats did not survive to discharge. Cats with neurologic injuries were more likely not to survive $(P=.02)$.

Conclusion: Concurrent injuries to at least one body region, especially the abdomen and thorax, were observed in cats sustaining pelvic fractures. Mortality was associated with increased severity of the fractures, neurologic injuries, and increased number of concurrent injuries.

Clinical significance: Concurrent injuries are common in cats with pelvic fractures, and comorbidities may be associated with mortality.
\end{abstract}

This study was presented as a short abstract at the 28 th Annual Scientific Meeting of the European College of Veterinary Surgeons; July 4-6, 2019; Budapest, Hungary.

\section{1 | INTRODUCTION}

Pelvic fractures represent $20 \%$ to $32 \%$ of all feline fractures $^{1-3}$ and occur most commonly due to blunt trauma, such as road traffic accidents and high-rise syndrome. ${ }^{3-5}$ 
Among 100 consecutive feline trauma patients reviewed radiographically in one study, $34 \%$ were found to have pelvic injuries including pelvic fractures, sacroiliac joint luxations, and hip luxations. ${ }^{6}$ In cats with high-rise syndrome, $9 \%$ to $16 \%$ had pelvic fractures ${ }^{7,8}$ in contrast to $27 \%$ of cats involved in road traffic accidents. ${ }^{9}$

Additional injuries have been reported in $72 \%$ of cats with pelvic fractures, with fractures of the sacrum being the most common injury (19\% of cases), followed by femoral fractures and luxations and thoracic injuries. ${ }^{5}$ Strohbach ${ }^{10}$ found that more than $50 \%$ of concurrent injuries involved the soft tissues. Sciatic nerve dysfunction was another concurrent symptom in $11 \%$ to $23 \%$ of cats with pelvic fractures, ranging from mild to severe pelvic limb dysfunction. ${ }^{5,10,11}$ In dogs with traumatic pelvic fractures, concurrent intra-abdominal injuries were reported in $37 \%$ of cases, with hemoabdomen being the most common associated injury. ${ }^{12}$ No information regarding associated internal bleeding in cats with pelvic fractures was found in the literature.

Predictive factors for mortality in people with pelvic fractures have been identified as shock on arrival, head and neck injury, age, and the presence of other concurrent injuries. ${ }^{13-17}$ Similarly to human trauma patients, increased injury severity, measured by the Animal Trauma Triage Score, ${ }^{18}$ in dogs after vehicular trauma is associated with increased mortality. ${ }^{19}$ Head trauma in particular has been identified to decrease the survival rate significantly. ${ }^{20}$ In cats, spinal and abdominal injuries as well as an increasing number of injuries were associated with increased odds of death after vehicular trauma. ${ }^{21}$

Mortality rates in human patients presenting with pelvic fractures range from $8 \%$ to $19 \%{ }^{13,17,22}$ The severity of the injuries and the mortality in people is not only related to the type of pelvic fracture itself, but also to the comorbidities. Vaidya et $\mathrm{al}^{22}$ reported that the main cause of death within 6 hours was abdominal and pelvic hemorrhage, between 6 and 24 hours it was head injury, and after 24 hours it was multiple organ dysfunction syndrome. The overall mortality rate for feline trauma patients ranged from $9 \%$ to $27 \%,{ }^{4,6,9,23}$ while mortality in cases of high-rise syndrome ranged between $4 \%$ and $17 \% .^{7,8,24}$ To the best of the authors' knowledge, no published report has described the mortality rate in cats with pelvic fractures or investigated the association with risk factors.

The objective of this study was to describe fracture types, concurrent injuries, and outcomes of a population of cats with pelvic fractures and to identify factors associated with death. We hypothesized that (1) age, thoracic, abdominal, or facial trauma, and/or injuries to the central and peripheral nervous system would be associated with increased mortality and that (2) bilateral involvement of the weight-bearing elements of the pelvis would be associated with higher mortality.

\section{2 | MATERIALS AND METHODS}

\subsection{Study design}

The medical record database was searched for cats in which pelvic fractures had been diagnosed between January 2003 and November 2016. Cats were eligible for study inclusion when the information from the clinical examination at admission was available, either orthogonal (lateral and ventrodorsal) full-body radiographs or separate thoracic and abdominal radiographs including the entire pelvis were available, and an acute traumatic pelvic fracture was diagnosed. Cats were excluded when the medical records or radiographic examination was incomplete or radiographs were nondiagnostic.

Data obtained from the medical records included demographic information (sex, breed, age, weight, and client-owned or stray cat), mechanism of injury, administration of blood products, diagnosis of concurrent injuries, treatment of fracture (surgical vs conservative), number of general anesthesia events, and survival to discharge. The outcome in our study was defined as survival or nonsurvival to discharge.

The pelvic fractures were classified according to Messmer and Montavon ${ }^{25}$ on the basis of the pelvic, abdominal, or full-body radiographs in analog or digital format, depending on availability, and radiographic reports. Digital radiographs were analyzed in DICOM (Digital Imaging and Communications in Medicine) images with Horos software (v2.1.1; https://horosproject. org/). Radiographs were analyzed by a board-certified radiologist (F.D.C.) and a surgical resident (M.H.). This classification system consists of an alphanumeric code based on fracture configuration and anatomical location. Relevant fracture types therein include sacroiliac joint luxations, symphyseal separations, and fractures of the ilium, acetabulum, ischium, and pubis. The groups used in our study for statistical analysis are presented in Table 1.

Diagnosis of concurrent injuries was based on medical records, radiographs, and additional diagnostic tests when available (ultrasound, computed tomography, MRI, and laboratory tests). The injuries were grouped according to body regions, including the thorax, abdomen, central and peripheral nervous system, extremities, face, and soft tissue (Table 2). A "body region score" was calculated by counting the number of affected body regions with values from 0 (no injuries) to 6 (injuries to all six body regions present). This polytrauma scoring 
TA B LE 1 Classification system of the pelvic fractures according to Messmer and Montavon ${ }^{25}$

\begin{tabular}{|c|c|}
\hline Classification & Fracture site \\
\hline 61 & $\begin{array}{l}\text { Without involvement of weight- } \\
\text { bearing elements }\end{array}$ \\
\hline 61-A & $\begin{array}{l}\text { Pelvic margin (ilial wing, pubic } \\
\text { pecten, ischial tuberosity) }\end{array}$ \\
\hline $61-B$ & Pelvic floor \\
\hline $61-\mathrm{C}$ & Ischial body \\
\hline 62 & $\begin{array}{l}\text { Unilateral involvement of weight- } \\
\text { bearing elements }\end{array}$ \\
\hline $62-\mathrm{A}$ & Sacroiliac joint \\
\hline $62-\mathrm{B}$ & Ilial body \\
\hline $62-\mathrm{C}$ & Acetabulum \\
\hline 63 & $\begin{array}{l}\text { Bilateral involvement of weight- } \\
\text { bearing elements }\end{array}$ \\
\hline 63-A & Sacroiliac joint \\
\hline $63-\mathrm{B}$ & Ilial body \\
\hline $63-\mathrm{C}$ & Acetabulum \\
\hline+5 & Sacral fracture \\
\hline
\end{tabular}

Note: The pelvic fractures are assigned to one of the three principal categories $(61,62,63)$ and further subdivided into sacroiliac joint luxations, ilial body fractures, and acetabular fractures in cases of the involvement of the weight-bearing axis. In cases of a sacral fracture, the code +5 is added to the abbreviation.

system was developed on the basis of previous studies in dogs and cats with polytrauma. ${ }^{4,6,9,21,23}$

\section{2 | Statistical analysis}

Data were entered into a spreadsheet (Excel version 1906; Microsoft, Redmond, Washington), checked, and cleaned from duplicate records before further analysis. Descriptive statistics were used to report the data. Normality in the distribution of the data was assessed by visual inspection and a Shapiro-Wilk test. Continuous data were nonnormally distributed and are presented as median and range. Categorical data are presented as frequency and percentage.

Independence between categorical risk factors and the outcome were analyzed by using $\chi^{2}$ or Fisher's exact test. $P \leq .05$ was considered significant. The cats that survived were also analyzed for conservative vs surgical treatment of the pelvic fracture. Cases with missing data were not included in the analysis. Statistical analysis was performed in R Statistical Software version 3.5.1 (R Foundation for Statistical Computing, Vienna, Austria) by using the generalized linear models' function. Separate univariable logistic regression models were constructed to examine associations between potential risk factors and outcome.
TA B LE 2 Grouping of concurrent injuries to the six designated body regions

\begin{tabular}{|c|c|}
\hline Body region & Injury \\
\hline Thorax & $\begin{array}{l}\text { Pneumothorax, lung contusions, pleural } \\
\text { effusion, mediastinal effusion, } \\
\text { pneumomediastinum, bullae, } \\
\text { diaphragmatic hernia, rib fractures, } \\
\text { hypovolemia }\end{array}$ \\
\hline Abdomen & $\begin{array}{l}\text { Loss of abdominal or retroperitoneal } \\
\text { detail, pneumoperitoneum, abdominal } \\
\text { wall hernia, loss of abdominal wall } \\
\text { delineation, abdominal wall } \\
\text { thickening, hematuria, urinary bladder } \\
\text { rupture, hemoabdomen }\end{array}$ \\
\hline $\begin{array}{l}\text { Central and } \\
\text { peripheral } \\
\text { nervous } \\
\text { systems }\end{array}$ & $\begin{array}{l}\text { Proprioceptive and cranial nerve deficits, } \\
\text { peripheral nerve injuries, vertebral } \\
\text { fractures, brain injury }\end{array}$ \\
\hline Extremities & Fractures, luxations, joint instabilities \\
\hline Face & $\begin{array}{l}\text { Facial wounds and fractures, ocular } \\
\text { injuries, epistaxis, broken teeth, cleft } \\
\text { palate, mandibular symphysiolysis, } \\
\text { temporomandibular joint injuries }\end{array}$ \\
\hline Soft Tissue & $\begin{array}{l}\text { Abrasion wounds, lacerations, degloving } \\
\text { injuries, subcutaneous emphysema, } \\
\text { soft tissue swelling }\end{array}$ \\
\hline
\end{tabular}

Note: The total number of affected body regions generates the body region score with values from 0 (no other injuries) to 6 (injuries to all six body regions present).

For multivariable analysis, pelvic fractures were further grouped in the three main groups: 61 (fractures without involvement of the weight-bearing axis), 62 (unilateral involvement), and 63 (bilateral involvement). Multivariable logistic regression was then used to examine the variables that indicated loose associations with the outcome in the univariable analysis while accounting for confounding risk factors. A two-step model building approach was used. First, a conservative cutoff $(P<.2)$ was used to determine potential risk factors. Then, the risk factors were included in a multivariate model for multivariate analysis. Influential values were examined by the use of Cook's distance and inspection of the standardized residual error. Collinearity was checked in the final model by the variance inflation factors. Overall significance of risk factors was assessed by using a likelihood ratio test at level 5\%.

\section{3 | RESULTS}

\section{1 | Descriptive analysis}

Two hundred eighty cats met the inclusion criteria. The population included 142 male cats (50.7\%; 107/142 
castrated, 35/142 intact) and 127 female cats (45.4\%; $79 / 127$ spayed, 48/127 intact) with a median age of 2.2 years (range, $0.25-16.4$ ) and a median weight of $4 \mathrm{~kg}$ (range, 1.6-7.5). The most frequent causes of injury were road traffic accident (230/280 [82.1\%]) and high-rise syndrome (29/280 [10.4\%]; Table 3).

\subsection{Distribution of pelvic fractures}

One hundred thirty-four of $280(47.9 \%)$ cats sustained a pelvic fracture with bilateral involvement, 120/280 (42.9\%) with unilateral involvement, and 26/280 (9.3\%) without involvement of the weight-bearing axis (groups

TA B LE 3 Descriptive statistics of 280 cats with traumatic pelvic fractures

\begin{tabular}{|c|c|c|c|c|c|c|}
\hline Variable & $\mathbf{n}$ & $\%$ & Median & Range & Mean & SD \\
\hline Client-owned cat & 258 & 92.1 & & & & \\
\hline Stray cat & 22 & 7.9 & & & & \\
\hline Age, y & 240 & 85.7 & 2.2 & $0.25-16.4$ & & \\
\hline Weight, kg & 271 & 96.8 & 4.0 & $1.6-7.5$ & & \\
\hline \multicolumn{7}{|l|}{ Sex } \\
\hline Female intact & 48 & 17.1 & & & & \\
\hline Female spayed & 79 & 28.2 & & & & \\
\hline Male intact & 35 & 12.5 & & & & \\
\hline Male castrated & 107 & 38.2 & & & & \\
\hline Unknown & 11 & 3.9 & & & & \\
\hline \multicolumn{7}{|l|}{ Cause } \\
\hline Hit by car & 230 & 82.1 & & & & \\
\hline High-rise syndrome & 29 & 10.4 & & & & \\
\hline Other & 4 & 1.4 & & & & \\
\hline Unknown & 17 & 6.1 & & & & \\
\hline \multicolumn{7}{|l|}{ Pelvic fractures grouped } \\
\hline 61 & 26 & 9.3 & & & & \\
\hline 62 & 120 & 42.9 & & & & \\
\hline 63 & 134 & 47.9 & & & & \\
\hline \multicolumn{7}{|l|}{$\begin{array}{l}\text { Treatment of pelvic } \\
\text { fractures }\end{array}$} \\
\hline Surgical & 164 & 58.6 & & & & \\
\hline Conservative & 69 & 24.6 & & & & \\
\hline Untreated & 47 & 16.8 & & & & \\
\hline Blood transfusion & 14 & 5.0 & & & & \\
\hline $\begin{array}{l}\text { Number of procedures } \\
\text { under anesthesia }\end{array}$ & 193 & 68.9 & 1.0 & $0-6$ & & \\
\hline Body region score & 280 & 100 & 2.0 & $0-5$ & 2.4 & 1.2 \\
\hline 0 & 18 & 6.4 & & & & \\
\hline 1 & 54 & 19.3 & & & & \\
\hline 2 & 71 & 25.4 & & & & \\
\hline 3 & 85 & 30.4 & & & & \\
\hline 4 & 43 & 15.4 & & & & \\
\hline 5 & 9 & 3.2 & & & & \\
\hline 6 & 0 & 0 & & & & \\
\hline Mortality & 56 & 20 & & & & \\
\hline
\end{tabular}


FIGURE 1 Frequencies (red) and mortality rates (black) of the grouped pelvic fractures
F I G U RE 2 Type of treatment according to the type of pelvic fracture. Note the tendency toward surgical treatment when the weightbearing axis is involved, especially for ilial and acetabular fractures, in contrast to conservative treatment in non-weight-bearing fractures
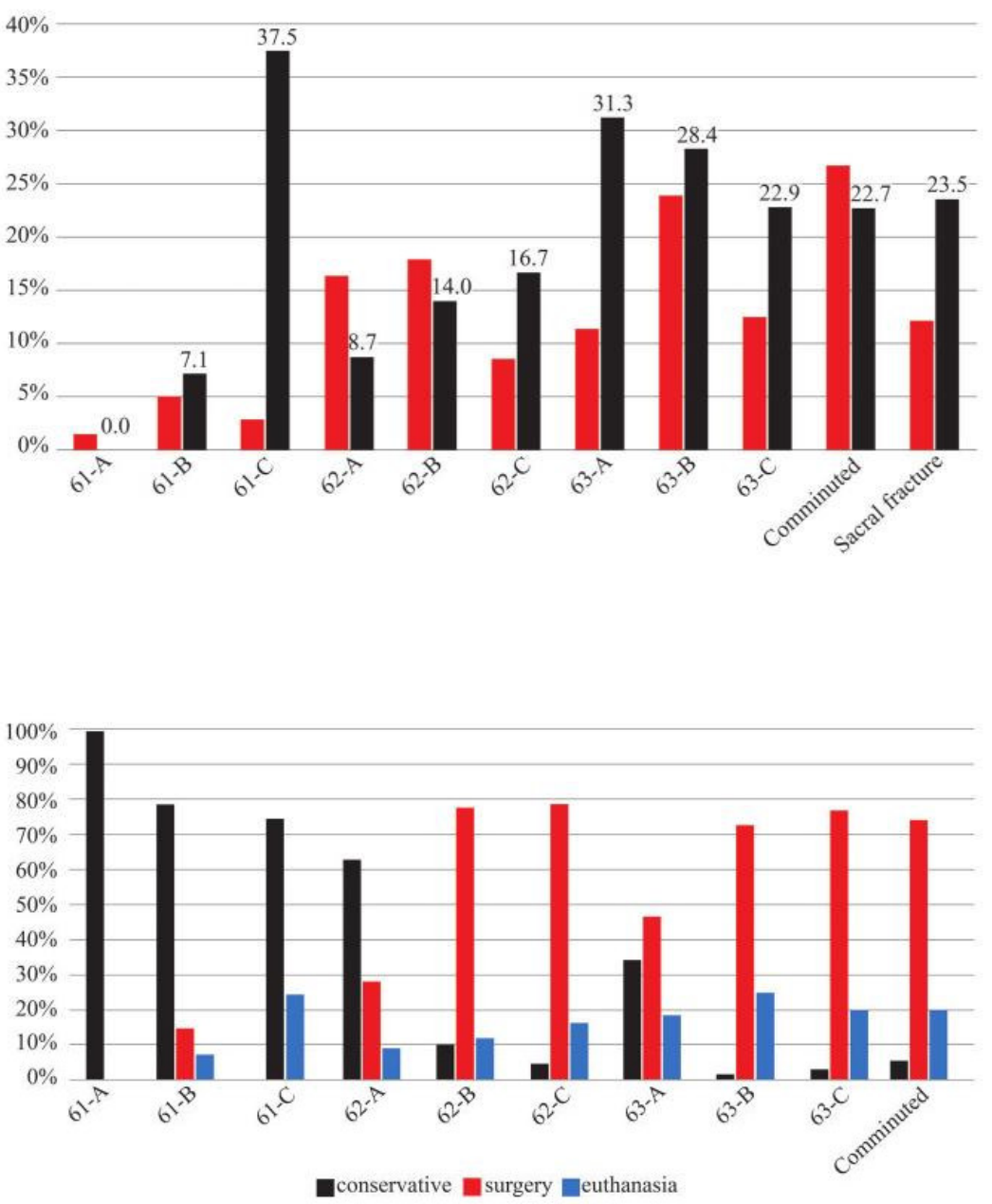

63-, 62-, and 61-A/B/C, respectively). Sacral fractures occurred in $12.1 \%(34 / 280$; Figure 1$)$ of cats. The occurrence of sacral fractures was not associated with the type of pelvic fracture $(P=.20)$.

\subsection{Treatment of pelvic fractures}

Pelvic fractures were surgically treated in $164(58.6 \%)$ cases and conservatively treated in 69 (24.6\%) cases. Forty-seven (16.8\%) cats died or were euthanized before a specific treatment of the pelvic fracture was assigned (Table 3). Sixty-five of 69 (94.2\%) conservatively treated cases were noncomminuted. Surgery and euthanasia were more common in cats with comminuted or more severe fractures, and conservative treatment was more common in cats with simpler fractures $(P<.0001$; Figure 2). This was also reflected in a positive association of comminuted pelvic fractures with the type of treatment, with cats that had comminuted pelvic fractures treated surgically in $74.7 \%(56 / 75)$ of cases, euthanized in
$20.0 \%(15 / 75)$, and treated conservatively in $5.3 \%(4 / 75$; $P<.0001)$.

\subsection{Additional injuries and acquired conditions}

Two hundred sixty-two of $280(93.6 \%)$ cats had at least one additional injury to the defined body regions. This involved the abdomen in $57.5 \%(161 / 280)$ of cats, the tho$\operatorname{rax}$ in $49.6 \%(139 / 280)$, the soft tissue in $48.6 \%(136 / 280)$, the central and peripheral nervous system in $43.6 \%$ $(122 / 280)$, the extremities in $25.4 \%(71 / 280)$, and the face in $13.9 \%(39 / 280)$. Mean \pm SD of the body region score was $2.4 \pm 1.2$ and was associated with mortality $(P<.01$; Tables 3 and 4). An association was found between the cause of the trauma and the occurrence of thoracic $(P=.003)$, abdominal $(P=.002)$, and soft tissue injuries $(P=.004)$ and injuries to the central and peripheral nervous system ( $P=.002$; Figure 3$)$. The most common finding in vehicular trauma cases was an abdominal injury in 
T A B LE 4 Univariable logistic regression analysis for risk factors for death in cats with traumatic pelvic fractures

\begin{tabular}{|c|c|c|c|c|c|c|c|}
\hline Variable & $\mathbf{n}$ & $\%$ & Death & $\%$ & OR $(95 \% \mathrm{CI})$ & $P$-value & Overall $P$-value \\
\hline Age, mo & 240 & 85.7 & & & $0.994(0.982-1.005)$ & .296 & .2927 \\
\hline \multicolumn{8}{|l|}{ Sex } \\
\hline Female intact & 48 & 17.1 & 12 & 25.00 & Reference & & .434 \\
\hline Female spayed & 79 & 28.2 & 12 & 15.19 & $0.537(0.217-1.326)$ & .175 & \\
\hline Male intact & 35 & 12.5 & 8 & 22.86 & $0.889(0.310-2.454)$ & .822 & \\
\hline Male castrated & 107 & 38.2 & 20 & 18.69 & $0.690(0.308-1.589)$ & .371 & \\
\hline Unknown & 11 & 3.9 & 4 & 36.36 & $1.714(0.393-6.769)$ & .448 & \\
\hline Weight, continuous, kg & 271 & 96.8 & & & $0.991(0.973-1.010)$ & .354 & .3517 \\
\hline \multicolumn{8}{|l|}{ Pelvic fractures grouped } \\
\hline $61-\mathrm{A} / \mathrm{B} / \mathrm{C}$ & 26 & 9.3 & 4 & 15.38 & Reference & & .0791 \\
\hline $62-\mathrm{A}$ & 46 & 16.4 & 4 & 8.70 & $0.524(0.114-2.406)$ & .391 & \\
\hline $62-B$ & 50 & 17.9 & 7 & 14.00 & $0.895(0.243-3.721)$ & .871 & \\
\hline $62-\mathrm{C}$ & 24 & 8.6 & 4 & 16.67 & $1.100(0.232-5.220)$ & .902 & \\
\hline 63-A & 32 & 11.4 & 10 & 31.25 & $2.500(0.717-10.235)$ & .168 & \\
\hline $63-\mathrm{B}$ & 67 & 23.9 & 19 & 28.36 & $2.177(0.715-8.178)$ & .200 & \\
\hline $63-\mathrm{C}$ & 35 & 12.5 & 8 & 22.86 & $1.630(0.450-6.772)$ & .470 & \\
\hline$+5^{\mathrm{a}}$ No & 246 & 87.9 & 48 & 19.51 & Reference & & .5897 \\
\hline$+5^{\mathrm{a}}$ Yes & 34 & 12.1 & 8 & 23.53 & $1.269(0.510-2.870)$ & .584 & \\
\hline Comminuted No & 205 & 73.2 & 39 & 19.02 & Reference & & .504 \\
\hline Comminuted Yes & 75 & 26.8 & 17 & 22.67 & $1.248(0.644-2.345)$ & .5 & \\
\hline \multicolumn{8}{|l|}{ Body region injuries } \\
\hline Thorax No & 141 & 50.4 & 23 & 16.31 & Reference & & .1195 \\
\hline Thorax Yes & 139 & 49.6 & 33 & 23.74 & $1.597(0.886-2.919)$ & .122 & \\
\hline Abdomen No & 119 & 42.5 & 22 & 18.49 & Reference & & .5854 \\
\hline Abdomen Yes & 161 & 57.5 & 34 & 21.12 & $1.180(0.653-2.169)$ & .587 & \\
\hline CNS and PNS No & 158 & 56.4 & 24 & 15.19 & Reference & & .0225 \\
\hline CNS and PNS Yes & 122 & 43.6 & 32 & 26.23 & $1.985(1.101-3.621)$ & .023 & \\
\hline Extremities No & 209 & 74.6 & 40 & 19.14 & Reference & & .5404 \\
\hline Extremities Yes & 71 & 25.4 & 16 & 22.54 & $1.229(0.625-2.333)$ & .537 & \\
\hline Face No & 241 & 86.1 & 48 & 19.92 & Reference & & .9314 \\
\hline Face Yes & 39 & 13.9 & 8 & 20.51 & $1.038(0.422-2.306)$ & .931 & \\
\hline Soft tissue No & 144 & 51.4 & 24 & 16.67 & Reference & & .151 \\
\hline Soft tissue Yes & 136 & 48.6 & 32 & 23.53 & $1.538(0.855-2.800)$ & .153 & \\
\hline Body region score, continuous & 280 & 100 & & & $1.387(1.085-1.792)$ & .01 & .0086 \\
\hline Blood transfusion No & 266 & 95.0 & 55 & 20.68 & Reference & & .1691 \\
\hline Blood transfusion Yes & 14 & 5.0 & 1 & 7.14 & $0.295(0.016-1.531)$ & .245 & \\
\hline Number of procedures & 193 & 68.9 & 13 & 6.74 & $0.126(0.065-0.232)$ & $<.001$ & $<.001$ \\
\hline \multicolumn{8}{|l|}{ under anesthesia, continuous } \\
\hline \multicolumn{8}{|l|}{ Cause } \\
\hline Hit by car & 230 & 82.1 & 48 & 20.87 & Reference & & .5196 \\
\hline High-rise syndrome & 29 & 10.4 & 3 & 10.34 & $0.438(0.101-1.311)$ & .190 & \\
\hline Other & 4 & 1.4 & 1 & 25.00 & $1.264(0.062-10.121)$ & .841 & \\
\hline Unknown & 17 & 6.1 & 4 & 23.53 & $1.67(0.318-3.469)$ & .795 & \\
\hline
\end{tabular}

Abbreviations: $95 \% \mathrm{CI}$, 95\% confidence interval; CNS, central nervous system; OR, odds ratio; PNS, peripheral nervous system.

${ }^{a}+5$, sacral fracture.

*Likelihood ratio test. 
F I G URE 3 Injuries to the defined body regions in 280 cats with pelvic fractures in relation to the cause of injury. Note that thoracic, abdominal, central and peripheral nervous system, and soft tissue injuries are associated with the cause (all

$P \leq .05)$. Abbreviation: HBC, hit by car

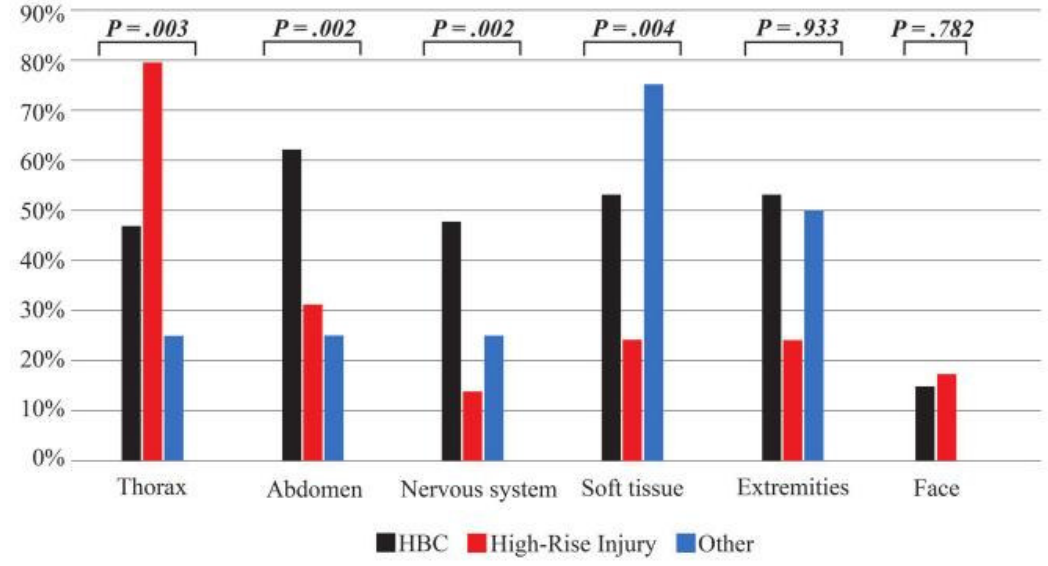

TA B LE 5 Multivariable logistic regression analysis for risk factors for death prior to discharge in cats with traumatic pelvic fractures

\begin{tabular}{|c|c|c|c|}
\hline Variable & OR $(95 \% \mathrm{CI})$ & $P$-value & Overall $P$-value* \\
\hline \multicolumn{4}{|l|}{ Pelvic fractures grouped } \\
\hline $61-\mathrm{A} / \mathrm{B} / \mathrm{C}$ & Reference & & .0012 \\
\hline $62-\mathrm{A} / \mathrm{B} / \mathrm{C}$ & $0.993(0.279-4.160)$ & .992 & \\
\hline $63-\mathrm{A} / \mathrm{B} / \mathrm{C}$ & $4.003(1.150-16.931)$ & .040 & \\
\hline \multicolumn{4}{|l|}{ Body region injuries } \\
\hline Thorax No & Reference & & .5012 \\
\hline Thorax Yes & $0.729(0.285-1.829)$ & .502 & \\
\hline CNS and PNS No & Reference & & .4145 \\
\hline CNS and PNS Yes & $0.687(0.273-1.691)$ & .416 & \\
\hline Soft tissue No & Reference & & .950 \\
\hline Soft tissue Yes & $1.032(0.381-2.786)$ & .950 & \\
\hline Body region score, continuous & $1.845(1.074-3.232)$ & .029 & .0265 \\
\hline Blood transfusion No & Reference & & .8904 \\
\hline Blood transfusion Yes & $1.181(0.041-0.0631)$ & .012 & \\
\hline Number of procedures & $0.069(0.029-0.147)$ & $<.001$ & $<.001$ \\
\hline under anesthesia, continuous & & & \\
\hline
\end{tabular}

Abbreviations: 95\% CI, 95\% confidence interval; CNS, central nervous system; OR, odds ratio; PNS, peripheral nervous system.

*Likelihood ratio test.

$62.2 \%(143 / 230)$ of cases, whereas in high-rise-syndrome cases a thoracic injury was more common (23/29 [79.3\%]; Figure 3).

\section{5 | Outcome}

The overall mortality rate was 20\% (56/280). Among these, $89.3 \%(50 / 56)$ of cats had been euthanized, and $10.7 \%(6 / 56)$ had died. The mortality rate for clientowned and stray cats was $17.4 \%(45 / 258)$ and $50.0 \%$ $(11 / 22)$, respectively. Among all nonsurviving cats, $91.1 \%$
(51/56) were euthanized or died before a specific treatment for the pelvic fracture was started. Among clientowned cats that did not survive, 20\% (9/45) were euthanized on the day of admission.

\section{6 | Risk factors for death}

Univariable analysis indicated associations $(P<.20)$ between grouped pelvic fractures, injuries to the thorax, the central and peripheral nervous system, soft tissues, body region score, blood transfusion, number of 
procedures under anesthesia, and death (Table 4). These variables were all carried forward for multivariable analysis. The grouped pelvic fractures, body region score, and number of procedures under anesthesia remained statistically significant (all $P \leq .05$ ) after having been controlled for confounding (Table 5). There was an association between an injury to the central and peripheral nervous system and death $(P=.023)$ but not for any other body region (Table 4). Cats with pelvic fractures involving the weight-bearing axis bilaterally had 2.5 (group 63-A), 2.2 (group 63-B), and 1.6 (group 63-C) times higher odds of death compared with cats with pelvic fractures without involvement of the weight-bearing axis and four times higher odds of death (groups 63-A/B/C) overall (Tables 4 and 5 ). The highest mortality rates were found in the pelvic fracture groups $61-\mathrm{C}(37.5 \%), 63-\mathrm{A}(31.3 \%)$, and $63-\mathrm{B}$ (28.4\%; Figure 1). An association between the type of pelvic fracture and outcome was found, with higher pelvic fracture classifications in euthanized cats $(P=.014)$. There was no association between mortality and the cause of injury $(P=.520)$, age $(P=.293)$, sacral fractures $(P=.590)$, or comminution of pelvic fractures $(P=.504$; Table 4). Decreased odds of death were associated with an increased number of procedures under anesthesia (odds ratio [OR] $0.07 ; 95 \%$ confidence interval [CI] $0.03-0.15 ; P<.001)$. An increasing body region score was associated with increased odds of death (OR 1.85; 95\%CI 1.07-3.23; $P=.026$; Table 5).

\section{4 | DISCUSSION}

In this study, the cats with pelvic fractures involving the weight-bearing axis bilaterally had a mortality rate $(27.6 \%)$ twice as high as cats with unilateral fractures (12.5\%). These cats had at least one additional body region injured, with a higher body region score associated with increased odds of death. In particular, cats with associated neurologic injuries had the highest mortality rate $(26.2 \%)$. In contrast, neither age and cause of injury nor thoracic, abdominal, or facial trauma was associated with survival in cats with traumatic pelvic fractures. Our findings are in agreement with Merbl et $\mathrm{al}^{7}$ and Conroy et $\mathrm{al}^{21}$ who found higher mortality rates when spinal injuries were present in cats with high-rise syndrome or trauma from road traffic accidents. We also confirm the finding of Conroy et $\mathrm{al}^{21}$ that an overall increased number of injuries is associated with increased odds of death. In our study, half of all cats had injuries to three or more body regions, which is similar to the report of Conroy et $\mathrm{al}^{21}{ }^{21}$ who found two or more injuries in half of all cats. ${ }^{21}$

The overall mortality rate in our study $(20 \%)$ was twice as high as that in dogs with pelvic fractures. ${ }^{12}$
Similar mortality rates have been reported in cats that experienced road traffic accidents and high-rise syndrome. ${ }^{7,9}$ Furthermore, we found that each additional body region injured increased the odds of death 1.85 -fold. A possible explanation for this higher mortality rate in cats is the higher occurrence of polytrauma injuries. The incidence of polytrauma in dogs with pelvic fractures was reported around $70 \%,{ }^{19,20}$ whereas, in our study, $94 \%$ of cats were affected by one or more body region injuries in addition to the pelvic fracture, and $74 \%$ were affected by two or more additional injuries. The smaller body mass in cats may be a predisposing factor for polytrauma in high-energy trauma such as vehicular and high-rise accidents.

The high incidence of abdominal injuries can be explained by the close anatomic location and, therefore, higher likelihood of accompanied injuries when a pelvic fracture is present. As previously described by Selcer, ${ }^{26}$ concurrent abdominal injuries involve especially the urinary tract. In the Selcer ${ }^{26}$ study, $39 \%$ of dogs with pelvic fractures had a urinary tract trauma that was clinically undetected in one-third of the cases. In contrast to the Selcer ${ }^{26}$ study, severe urinary tract trauma was suspected in only nine of our cases, finally leading to surgical intervention in four cases. Griffon et $\mathrm{al}^{27}$ reported the incidence of thoracic injuries to be $33 \%$ in cats with pelvic fractures, whereas, in our study, $50 \%$ of cats were affected. This might be explained by the high occurrence of vehicular accidents in our population, which had also been found to be a predisposing factor in the Griffon et $\mathrm{al}^{27}$ study.

Neither age nor the cause of injury was associated with survival in cats with traumatic pelvic fractures in our study. Survival was associated with the severity of pelvic fractures, concurrent neurological injuries, and the number of body regions involved. Head injury is a risk factor for higher mortality rates in people with pelvic fractures and in dogs with blunt trauma. ${ }^{13,20,22}$ In contrast, concurrent facial trauma was not associated with increased mortality in our feline study population, which might have been due to the low occurrence or lesser severity of the injuries. Because we specifically analyzed cats with pelvic fractures, the involvement of facial injuries might further be lower due to the opposite anatomic location of the main injury site. Comparison between studies is also complicated because the term head trauma often is not clearly defined and might include facial and/or brain injuries.

Our analysis of this population of cats with pelvic fractures provided evidence that the weight-bearing axis is involved in over $90 \%$ of cases and that bilateral involvement is found in $48 \%$ of cases. Similar frequencies were found in the original study about the pelvic fracture classification system published by Messmer and Montavon. ${ }^{25}$ 
In contrast, therein only $39 \%$ of cases had a bilateral involvement of the weight-bearing axis. This might have been due to the mixed population of cats and dogs in the latter study. In our study, bilateral involvement of the weight-bearing axis of the pelvis was correlated with a negative outcome with a fourfold higher risk of death (13.2\%) compared with cats with fractures without involvement of the weight-bearing axis (1.4\%). This reflects the severity of injury, but it might also be related to the owner's choice, influenced by the prognosis given or financial reasons.

We found that an injury to at least one additional body region must be expected in cats with pelvic fractures, with the abdomen most commonly affected in vehicular trauma cases $(62.2 \%)$ and the thorax more likely affected in cases of high-rise injury (79.3\%). The mean body region score was 2.4 in the cats in our study. This is in line with previous studies, in which it was also found that concurrent injuries are common in these high-energy trauma patients, such as road-traffic-accident and high-rise-syndrome cases. ${ }^{4,5,9,23}$ Although not associated with death, we found that more surgical procedures were implemented in cats with extremity or soft tissue injuries. An increasing number of anesthesia events provided a protective effect (each anesthetic event decreased the risk of death by 93\%) and, therefore, might indicate a higher standard of care. However, the clinical relevance of this finding is unknown because specific reasons for additional anesthesia events could not be determined retrospectively.

Cats with pelvic fractures involving the weightbearing axis at least unilaterally or having a comminuted pelvic fracture were more likely to be treated surgically or euthanized. In particular, a tendency toward surgical treatment was found in cats with more severe pelvic fractures. This is in line with current surgical guidelines, which state that a surgical treatment should be performed in the case of a narrowed pelvic canal, extreme pain, neurologic deficits as often present with ilial fractures, acetabular involvement, involvement of the weight-bearing elements, or the inability to walk after 3 days of conservative treatment. ${ }^{1,28}$ Surgical treatment of the pelvic fractures was performed in $59 \%$ of our study population, and conservative treatment was initiated in $25 \%$, which is similar to $26 \%$ of conservatively treated animals in a study of 43 cats by Meeson. ${ }^{11}$

Our study has several limitations. Data collection was limited to the information available in the medical records, so some variations in the quality of the data recorded are possible. In particular, information such as detailed clinical examination results, blood work, and blood pressure were not available for the whole population. Also, injuries might have been missed or misclassified. Because the traumatic event was not always directly observed by the owner, the cause of trauma might have been falsely recorded based on the highest probability according to additional injuries or location of retrieval of the cat. Because of the retrospective nature of the study, outcome was defined as survival to discharge. The decision governing the kind of treatment applied might have been influenced by the owner's choice, electing euthanasia rather than treatment depending on the severity of the injuries and prognosis given as well as financial reasons.

When our results are interpreted, it should be clear that euthanasia because of financial reasons or any other reason is an important factor influencing high nonsurvival rates, affecting $50(18 \%)$ cats in our study. This is almost twice as high as for dogs presented with severe blunt trauma. ${ }^{20}$ On the one hand, this might take into account the higher rate of polytrauma injuries and, therefore, poorer given prognosis. On the other hand, it gives the impression that dog owners may be more willing to take on the burdens of veterinary care compared with cat owners. Retrospectively, the reasons for euthanasia remain unclear, but nonetheless reflect the sum of decision making as they occur in everyday practice. Cats dying at the scene or shortly after could not have been included in this study; therefore, important additional data regarding this cohort were not available. The application of an animal trauma triage score would have added valuable information but was not possible because of the limited information available for review. Finally, the long time period of the study remains a point for discussion because of changes in medical treatment options and advancements in medical care over the years. A prospective study with a focus on detailed admission characteristics, blood work, and further diagnostics as well as long-term outcome will help to further refine risk factors for death in cats with traumatic pelvic fractures.

In conclusion, cats that experienced pelvic fractures including the weight-bearing axis of the pelvis bilaterally as well as cats with a concurrent neurologic injury had higher mortality rates. Concurrent injuries to at least one body region, specifically the abdomen in vehicular trauma cases and the chest in high-rise-syndrome cases, can be expected. Because these additional injuries have a negative impact on outcome, with each additional body region injured increasing the odds of death 1.85-fold, a complete workup for the cat is recommended before surgery of the pelvic fracture is considered. Additional studies are required to determine the long-term outcome of cats with pelvic fractures.

\section{CONFLICT OF INTEREST}

The authors declare no conflicts of interest related to this report. 


\section{ORCID}

Meike Hammer (D) https://orcid.org/0000-0001-9654-5344

\section{REFERENCES}

1. Lanz OI. Lumbosacral and pelvic injuries. Vet Clin North Am Small Anim Pract. 2002;32:949-962.

2. Whitney WO, Mehlhaff CJ. High-rise syndrome in cats. $J$ Am Vet Med Assoc. 1987;191:1399-1403.

3. Hill FW. A survey of bone fractures in the cat. J Small Anim Pract. 1977;18:457-463.

4. Kolata RJ, Kraut NH, Johnston DE. Patterns of trauma in urban dogs and cats: a study of 1000 cases. J Am Vet Med Assoc. 1974;164:499-502.

5. Bookbinder PF, Flanders JA. Characteristics of pelvic fracture in the cat. A 10-year retrospective study. Vet Comp Orthop Traumatol. 1992;5:122-127.

6. Zulauf D, Kaser-Hotz B, Hassig M, Voss K, Montavon PM. Radiographic examination and outcome in consecutive feline trauma patients. Vet Comp Orthop Traumatol. 2008;21:36-40.

7. Merbl Y, Milgram J, Moed Y, Bibring U, Peery D, Aroch I. Epidemiological, clinical and hematological findings in feline high rise syndrome in Israel: a retrospective case-controlled study of 107 cats. Isr J Vet Med. 2013;68:28-37.

8. Vnuk D, Pirkic B, Maticic D, et al. Feline high-rise syndrome: 119 cases (1998-2001). J Feline Med Surg. 2004;6:305-312.

9. Rochlitz I. Clinical study of cats injured and killed in road traffic accidents in Cambridgeshire. J Small Anim Pract. 2004;45:390-394.

10. Strohbach $\mathrm{K}$. Long-term evaluation of surgical fixation of pelvic fractures in the cat [Dissertation in German]. München, Germany: Tierärztliche Fakultät LMU München; 2007. http://nbnresolving.de/urn:nbn:de:bvb:19-73365.

11. Meeson RL, Geddes AT. Management and long-term outcome of pelvic fractures: a retrospective study of 43 cats. J Feline Med Surg. 2017;19:36-41.

12. Hoffberg JE, Koenigshof AM, Guiot LP. Retrospective evaluation of concurrent intra-abdominal injuries in dogs with traumatic pelvic fractures: 83 cases (2008-2013). J Vet Emerg Crit Care (San Antonio). 2016;26:288-294.

13. Sathy AK, Starr AJ, Smith WR, et al. The effect of pelvic fracture on mortality after trauma: an analysis of 63000 trauma patients. J Bone Joint Surg Am. 2009;91:28032810 .

14. Giannoudis PV, Grotz MR, Tzioupis C, et al. Prevalence of pelvic fractures, associated injuries, and mortality: the United Kingdom perspective. J Trauma. 2007;63:875-883.

15. Kido A, Inoue F, Takakura Y, Hoshida T. Statistical analysis of fatal bleeding pelvic fracture patients with severe associated injuries. J Orthop Sci. 2008;13:21-24.
16. Starr AJ, Griffin DR, Reinert CM, et al. Pelvic ring disruptions: prediction of associated injuries, transfusion requirement, pelvic arteriography, complications, and mortality. $J$ Orthop Trauma. 2002;16:553-561.

17. Parreira GJ, Coimbra R, Rasslan S, Oliveira A, Fregoneze M, Mercadante M. The role of associated injuries on outcome of blunt trauma patients sustaining pelvic fractures. Injury. 2000; 31:677-682.

18. Rockar RA, Drobatz KS, Shofer FS. Development of a scoring system for the veterinary trauma patient. J Vet Emerg Crit Care (San Antonio). 1994;4:77-83.

19. Streeter EM, Rozanski EA, Laforcade-Buress A, Freeman LM, Rush JE. Evaluation of vehicular trauma in dogs: 239 cases (January-December 2001). J Am Vet Med Assoc. 2009;235:405-408.

20. Simpson SA, Syring R, Otto CM. Severe blunt trauma in dogs: 235 cases (1997-2003). J Vet Emerg Crit Care (San Antonio). 2009;19:588-602.

21. Conroy M, O'Neill D, Boag A, Church D, Brodbelt D. Epidemiology of road traffic accidents in cats attending emergency-care practices in the UK. J Small Anim Pract. 2018;60:146-152.

22. Vaidya R, Scott AN, Tonnos F, Hudson I, Martin AJ, Sethi A. Patients with pelvic fractures from blunt trauma. What is the cause of mortality and when? Am J Surg. 2016;211:495-500.

23. Kolata RJ. Trauma in dogs and cats: an overview. Vet Clin North Am Small Anim Pract. 1980;10:515-522.

24. Vazquez L. Lesional and therapeutic study of the pelvis fractures in feline high-rise syndrome [Thesis in French]. Maisons-Alfort, France: École Nationale Vétérinaire d'Alfort; 2014. http://theses.vet-alfort. fr/telecharger.php?id=1818. Accessed December 10, 2019.

25. Messmer M, Montavon PM. Pelvic fractures in the dog and cat: a classification system and review of 556 cases. Vet Comp Orthop Traumatol. 2004;17:167.

26. Selcer BA. Urinary tract trauma associated with pelvic trauma. J Am Anim Hosp Assoc. 1982;18:785-793.

27. Griffon DJ, Walter PA, Wallace LJ. Thoracic injuries in cats with traumatic fractures. Vet Comp Orthop Traumatol. 1994;07:98-100.

28. Meeson R, Corr S. Management of pelvic trauma: neurological damage, urinary tract disruption and pelvic fractures. $J$ Feline Med Surg. 2011;13:347-361.

How to cite this article: Hammer M, Gutbrod A, Sigrist NE, et al. Predictors of comorbidities and mortality in cats with pelvic fractures. Veterinary Surgery. 2019;1-10. https://doi.org/10.1111/vsu. $\underline{13369}$ 


\section{Danksagung}

Hiermit bedanke ich mich herzlich bei meinem Doktorvater Antonio Pozzi für seine kontinuierliche Unterstützung und die kritische Durchsicht dieser Arbeit. Darüber hinaus danke ich ihm für die fortgesetzte Betreuung nach meinem Internship, was meine Verbundenheit zum Tierspital bis heute aufrechterhalten hat.

Mein herzlicher Dank gilt meinem Betreuer Andreas Gutbrod für seine Unterstützung bei der Erarbeitung der Studienidee und seiner kontinuierlichen Betreuung. Darüber hinaus danke ich Nadja Sigrist für ihr Engagement bei den zahlreichen Korrekturen und ihren wertvollen Beiträgen von ihrem Standpunkt der Notfall- und Intensivmedizin aus. Ein großer Dank geht an Valentine Jacot für ihre großartige Hilfe bei der Datensammlung und Literaturrecherche. Vielen Dank auch an Francesca Del Chicca für ihre Unterstützung bei der Auswertung der Röntgenbilder, sowie Richard Evans für seine Mithilfe bei der Statistik. Abschließend möchte ich mich herzlich beim ganzen Team der Kleintierchirurgie der Vetsuisse Fakultät Zürich für die Möglichkeit der Anfertigung dieser Dissertation bedanken. Die Zusammenarbeit mit diesem engagierten Team war eine Bereicherung und die Zeit am Tierspital wird mir weiterhin positiv in Erinnerung bleiben. Ein Dankeschön auch an meine Freunde, die mich in den letzten Jahren unterstützt haben, allen voran Simona.

Der größte Dank gilt meiner Familie, deren Liebe und Unterstützung mehrere Ländergrenzen in den letzten 4 Jahren überschritten haben; vor allem meiner Mutter für ihr immer offenes Ohr, ihren stetigen Rückhalt und ihre zahlreichen „CARE-Pakete“ gefüllt mit Nervennahrung und aufmunternden Worten; und vor allem meinem Vater und Opa, die wohl die einzigen Menschen gewesen wären, die in diesem Moment noch glücklicher und stolzer gewesen wären, als ich es selber sein kann. 
5 Curriculum Vitae

\begin{tabular}{|c|c|}
\hline Vorname Name & Meike Hammer \\
\hline Geburtsdatum & 30.10 .1987 \\
\hline Geburtsort & Dorsten, Deutschland \\
\hline \multirow[t]{2}{*}{ Nationalität } & Deutsch \\
\hline & Schulausbildung \\
\hline $\begin{array}{l}08 / 1994-07 / 1998 \\
08 / 1998-06 / 2007\end{array}$ & $\begin{array}{l}\text { Grundschule, St. Agatha, Dorsten, Deutschland } \\
\text { Gymnasium Petrinum, Dorsten, Deutschland }\end{array}$ \\
\hline & Höchster Schulabschluss \\
\hline $15 / 06 / 2007$ & Abitur, Gymnasium Petrinum, Dorsten, Deutschland \\
\hline & Studium \\
\hline $10 / 2007-03 / 2013$ & $\begin{array}{l}\text { Veterinärmedizin, Universität Leipzig, Leipzig, } \\
\text { Deutschland }\end{array}$ \\
\hline $01 / 03 / 2013$ & $\begin{array}{l}\text { Abschlussprüfung vet. med. } \\
\text { Universität Leinzio Jeinzig Deutschland }\end{array}$ \\
\hline $08 / 2016-10 / 2020$ & $\begin{array}{l}\text { Anfertigung der Dissertation } \\
\text { unter Leitung von Prof. Dr. med. vet. Antonio Pozzi } \\
\text { DECVS, DACVS, DACVSMR } \\
\text { am Departement für Kleintiere, Klinik für } \\
\text { Kleintierchirurgie } \\
\text { der Vetsuisse-Fakultät Universität Zürich } \\
\text { Vorsteher: Prof. Dr. med. vet. Antonio Pozzi DECVS, } \\
\text { DACVS, DACVSMR }\end{array}$ \\
\hline
\end{tabular}

Alle fachrelevanten Anstellungen nach Abschluss des veterinärmedizinischen Studiums

03/2013 - 05/2013 Assistenzstelle, Tierarztpraxis Dr. Hammer, Dorsten, Deutschland

$06 / 2013-09 / 2014$

$10 / 2014-03 / 2016$

Assistenzstelle, Tierklinik Hofheim, Hofheim am Taunus, Deutschland Internship-Stelle, Departement für Kleintiere, Klinik für Kleintierchirurgie, Tierspital Zürich, Zürich, Schweiz Assistenzstelle, Departement für Kleintiere, Klinik für Kleintierchirurgie, Tierspital Zürich, Zürich Schweiz ECVS Residency-Stelle, Clinique Vétérinaire Aquivet, Eysines, Frankreich

$08 / 2020-10 / 2020$ Oberärztin, Schwerpunkt Weichteilchirurgie, Clinique Vétérinaire Aquivet, Eysines, Frankreich 